\title{
SIFAT FISIKA TANAH DAN PRODUKTIVITAS KELAPA SAWIT (Elaeis guineensis Jacq.) DI LAHAN GAMBUT PADA KEDALAMAN MUKA AIR TANAH YANG BERBEDA
}

\author{
(Soil Physical Properties and Productivity of Oil Palm (Elaeis guineensis Jacq.) in Peatland with \\ Different of Water Levels) \\ WAWAN WAWAN, AL ICHSAN AMRI, AFTA NURWANTO AKBAR \\ Program Studi Agroteknologi, Fakultas Pertanian, Universitas Riau \\ Kampus Bina Widya KM12,5 Simpang Baru - Pekanbaru 28293 \\ E-mail: aftanurwanto@gmail.com
}

\begin{abstract}
This study aims to determine soil physical properties and oil palm productivity in different of water levels (TMA) in peatland. This study conducted in oil palm plantation area in PT. Tabung Haji Indo Plantation Indragiri Hilir Regency, and Laboratory of Soil Science Faculty of Agriculture, University of Riau. This study was carried out started from July until October 2017 by using survey method. Sampling Location conducted by purposive sampling, and sampling point was determined by stratified random sampling. Analysed data used analyse of variance, followed by further test by Duncan's new multiple range test level of 5\%. Parameters observed in physical properties ware bulk density, porosity, water content of maximum occupied capacity, particles size distribution, and oil palm productivity. The result of this study showed that peatland with water levels (20-40) $\mathrm{cm}\left(T M A_{1}\right)$ showed higher water content of maximum occupied capacity than water levels $(>40-60) \mathrm{cm}\left(T M A_{2}\right)$, and $>60$ $\mathrm{cm}\left(\mathrm{TMA}_{3}\right)$. Peat soil with water level $T M A_{2}$ owned bulk density, the particle size $(\leq 63 \mu \mathrm{m})$ higher compared to (20-40) $\mathrm{cm}$ and $>60 \mathrm{~cm}$. Peat soil with $\mathrm{TMA}_{3}$ showed higher porosity compared to (20-40) $\mathrm{cm}$ and $(20-40) \mathrm{cm}$. Peat soil $(20-40) \mathrm{cm}$ showed higher oil palm productivity compared to $(>40-60) \mathrm{cm}$ and $>60 \mathrm{~cm}$. Oil palm productivity $(>40-60) \mathrm{cm}$ and $>60 \mathrm{~cm}$ showed lower compared to $(20-40) \mathrm{cm}$ is caused by Ganoderma attack.
\end{abstract}

Keywords: Soil Physical Properties, Water Levels, Oil palm Productivity

\section{PENDAHULUAN}

Perkebunan kelapa sawit pada lahan gambut memerlukan sistem drainase sebagai pengatur kedalaman muka air tanah. Kedalaman muka air yang sesuai dapat menjaga kelembaban tanah dan meningkatkan aerasi. Aerasi yang baik dapat mempengaruhi perakaran sehingga meningkatkan serapan hara, air serta produktivitas kelapa sawit.

Pentingnya penanganan lahan gambut menyebabkan pemerintah mengeluarkan peraturan melalui Menteri Pertanian Nomor 14 Tahun 2009 tentang pengaturan air pada saluran drainase disesuaikan dengan kedalaman permukaan air tanah di lapangan yang dipertahankan pada kedalaman $60 \mathrm{~cm}$ sampai dengan 80 $\mathrm{cm}$, untuk menjaga ketersediaan air dan menghindari lahan mudah terbakar. Kebakaran lahan masih banyak terjadi di lahan gambut sehingga pemerintah menerbitkan Peraturan Pemerintah No 57 tahun 2016. Pasal 23 ayat 3 pada Peraturan Pemerintah tersebut menyatakan bahwa ekosistem gambut dengan fungsi budidaya dinyatakan rusak apabila kedalaman muka air tanah di lahan gambut lebih dari $40 \mathrm{~cm}$ di bawah permukaan gambut pada titik penataan. Menurut informasi dari hasil penelitian Winarna (2015), kedalaman muka air tanah (30-50) cm mengasilkan produksi kelapa sawit lebih besar dibandingkan dengan kedalaman (45-70) $\mathrm{cm}$. Hal tersebut berbanding terbalik dengan hasil penelitian Lim et al. (2012) yang menyatakan bahwa produksi kelapa sawit akan menurun pada kedalaman muka air tanah gambut (35-45) cm dan pada kedalaman (50-75) cm kelapa sawit mencapai produksi tertinggi. Hal ini menandakan bahwa masih ada inkonsistensi informasi terhadap kedalaman muka air tanah gambut yang sesuai untuk meningkatkan produksi kelapa sawit, sehingga diperlukan adanya penelitian tambahan untuk dapat melihat kedalaman muka air tanah yang optimal terhadap produktivitas kelapa sawit.

Produksi kelapa sawit yang tinggi adalah manifestasi dari sifat-sifat tanah yang baik, salah satunya sifat fisika tanah. Pengaruh pengaturan kedalaman muka air tanah terhadap sifat fisika tanah yaitu dapat 
meningkatkan aerasi sehingga mempengaruhi perkembangan akar. Perkembangan akar yang baik akan meningkatkan serapan hara, air dan produksi kelapa sawit. Menurut Winarna (2015), penurunan muka air tanah lebih dari $70 \mathrm{~cm}$ menyebabkan terjadinya penurunan kelembaban tanah yang dapat mengakibatkan tanah gambut rusak. Kedalaman muka air tanah yang terkendali menyebabkan air dan udara menjadi lebih tersedia di dalam tanah gambut (Sukarman, 2011). Kondisi ini memicu tingginya aktivitas biota tanah sehingga meningkatnya proses dekomposisi dan menghasilkan tanah berpartikel halus yang berperan sebagai perekat (pengikat) partikel tanah sehingga agregasi tanah menjadi baik dan bulk density tanah gambut meningkat (Situmorang et al., 2015). Bulk density adalah salah satu pengukuran yang penting untuk menafsirkan data analisis tanah, terutama yang menunjukkan kesuburan (Andriesse, 2003).

Hubungan antara kedalaman muka air tanah dengan sifat fisika tanah dikaitkan dengan produktivitas kelapa sawit masih jarang dilakukan. Penelitian ini dilakukan untuk menambah informasi dan data kedalaman muka air dalam, sedang dan dangkal yang dihubungkan dengan produktivitas kelapa sawit dan sifat fisika tanah.

Penelitian ini bertujuan untuk mengetahui sifat fisika tanah dan produktivitas kelapa sawit pada kedalaman muka air tanah yang berbeda di lahan gambut.

\section{METODOLOGI}

Penelitian ini dilakukan di lahan gambut pada tanaman kelapa sawit PT. Tabung Haji Indo Plantation (PT. THIP) Indragiri Hilir dan Laboratorium IImu Tanah
Fakultas Pertanian Universitas Riau, Kampus Bina Widya, kilometer 12,5 Kelurahan Simpang Baru, Kecamatan Tampan, Pekanbaru. Penelitian ini dilaksanakan darii bulan Juli sampai dengan Oktober 2017.

Pada penelitian ini bahan yang digunakan pada penelitian ini adalah sampel tanah gambut pada tiga strata kedalaman muka air yaitu $(20-40) \mathrm{cm}$, $(>40-60) \mathrm{cm},>60 \mathrm{~cm}, \mathrm{NaOH}$ dan aquades.

Alat yang digunakan dalam penelitian di lapangan yaitu ring sampel, bor gambut, kamera, kantong plastik, selotip, karet gelang, cangkul, pisau lapangan, kertas label, alat tulis, oven, eksikator, timbangan analitik, grinder, erlenmeyer, cawan alumunium, mesin pengkocok dan saringan tanah berbagai ukuran.

Penelitian ini dilakukan di lahan gambut dengan tanaman kelapa sawit berumur 19 tahun. Penelitian ini menggunakan metode survei, lokasi penelitian ditentukan secara Purposive sampling dan titik pengambilan sampel ditentukan secara stratified random sampling. Penelitian menggunakan 27 titik sampel yang terbagi atas tiga strata kedalaman muka air tanah pada tiga blok yang berbeda di kedalaman muka air (2040) $\mathrm{cm},(>40-60) \mathrm{cm}$ dan $>60 \mathrm{~cm}$.

Data yang diperoleh dianalisis secara statistik dengan menggunakan sidik ragam atau analysis of variance (ANOVA) dan hasil sidik ragam dilanjukan dengan uji duncan's new multiple range test (DNMRT) pada taraf $5 \%$.

\section{HASIL DAN PEMBAHASAN}

\section{Kadar Air Kapasitas Lapang Maksimum}

Hasil sidik ragam menunjukkan bahwa faktor kedalaman muka air tanah berpengaruh terhadap kadar air kapasitas lapang maksimum di lahan gambut pada kedalaman tanah (0-10) $\mathrm{cm}$ (Tabel 1).

Tabel 1. Rata-rata kadar air kapasitas lapang maksimum di kedalaman $(0-10) \mathrm{cm}$ pada kedalaman muka air tanah gambut yang berbeda.

\begin{tabular}{cc}
\hline Kedalaman muka air (cm) & Kadar Air Kapasitas lapang Maksimum (\%) \\
\hline $20-40$ & $449,22^{\mathrm{a}}$ \\
$>40-60$ & $438,11^{\mathrm{b}}$ \\
$>60$ & $442,55^{\mathrm{ab}}$ \\
\hline Keterangan: Angka-angka yang diikuti oleh huruf kecil yang sama berbeda tidak nyata menurut uji &
\end{tabular}

Tabel 1 menunjukkan bahwa tanah gambut pada kedalaman muka air tanah
(20-40) cm dapat meningkatkan kadar air kapasitas lapang maksimum secara nyata 
dibandingkan dengan kedalaman muka air tanah $(>40-60) \mathrm{cm}$, namun berbeda tidak nyata dengan kedalaman muka air tanah $>60 \mathrm{~cm}$. Hal ini karena kedalaman muka air tanah (20-40) $\mathrm{cm}$ menyebabkan proses dekomposisi menjadi terhambat dibandingkan kedalaman muka air tanah $>60 \mathrm{~cm}$ dan $(>40-60) \mathrm{cm}$ sehingga ketersedian bahan organik yang masih belum terdekomposisi daripada kedalaman muka air lain. Bahan organik mempunyai kemampuan menyerap dan menahan air yang tinggi, bahan organik dapat menyerap air sebesar dua hingga tiga kali beratnya (Arsyad, 2000)

Peningkatan dekomposisi bahan organik mengakibatkan berkurangnya porositas total (Wahyunto et al., 2005). Kadar air kapasitas lapang tanah gambut berkaitan erat dengan porositas (Tabel 3), semakin tinggi porositas tanah maka semakin tinggi kemampuan tanah untuk menahan air. Menurut Radjaguguk (2000), porositas total sangat menentukan besarnya pengikatan air oleh tanah gambut. Bahan yang relatif belum terdekomposisi mempunyai porositas yang tinggi dengan proporsi pori-pori besar yang tinggi (Driessen \& Rochimah, 1976). Walaupun demikian daya menahan air dari gambut bervariasi, karena adanya interaksi yang komplek dari berbagai sifat tanah gambut tersebut (Wahyunto et al., 2005).

Porositas atau volume pori total tanah adalah bagian/rongga tanah yang tidak terisi bahan padat sehingga dapat diisi oleh udara dan air (Dikas, 2010). Besaran nilai porositas tanah (Tabel 3) berbanding terbalik terhadap besaran nilai bulk density (Tabel 2). Penurunan nilai bulk density meningkatkan daya menahan air tanah gambut (Tahrun et al., 2015). Kapasitas lapang di tanah gambut yang relatif tinggi, berdasarkan berat kering tanah gambut (Radjaguguk, 2000). Kapasitas menahan air maksimum untuk gambut fibrik adalah $(680-3000) \%$, untuk gambut hemik (450-850)\%, untuk gambut saprik $<450 \%$. Namun demikian, gambut akan menjadi hidrob (Menolak air) kalau terlalu kering (Radjaguguk, 2000). Tanah gambut terlalu kering dapat disebabkan oleh semakin dalamnya kedalaman muka air tanah.

\section{Bulk density}

Hasil sidik ragam menunjukkan bahwa faktor kedalaman muka air tanah berpengaruh nyata terhadap Bulk density (BD) di lahan gambut (Tabel 2).

Tabel 2. Rata-rata bulk density di kedalaman $(0-10) \mathrm{cm}$ pada kedalaman muka air tanah gambut yang berbeda.

\begin{tabular}{cc}
\hline Kedalaman muka air $(\mathrm{cm})$ & Bulk density $\left(\mathrm{g} \cdot \mathrm{cm}^{-3}\right)$ \\
\hline $20-40$ & $0,26^{\mathrm{b}}$ \\
$>40-60$ & $0,31^{\mathrm{a}}$ \\
$>60$ & $0,22^{\mathrm{b}}$
\end{tabular}

Keterangan: Angka-angka yang diikuti oleh huruf kecil yang sama berbeda tidak nyata menurut uji DNMRT pada taraf $5 \%$

Tabel 2 menunjukkan pada lahan gambut dengan kedalaman muka air tanah (>40-60) cm memiliki nilai bulk density tertinggi dibandingkan dengan dua ketinggian air diatas. Hal ini karenakan kondisi lahan yang tidak terlalu jenuh air, sehingga mendukung aktivitas berkembangbiak organisme tanah yang dapat memepercepat proses dekomposisi.

Hasil pengamatan organisme tanah menunjukkan pada kedalaman muka air (>40-60) memiliki jumlah makrofauna tertinggi yaitu sebesar 287 individu, kedalaman muka air (20-40) $\mathrm{cm}$ dan $>60$ $\mathrm{cm}$ memiliki jumlah makrofauna tanah yaitu berturut-turut memiliki 245 dan 140 individu per $2.500 \mathrm{~cm}^{2}$. Semakin banyak organisme pada tanah maka laju proses dekomposisi meningkat, meningkatnya proses dekomposisi memperbesar nilai bulk density. Kedalaman muka air tanah gambut ( $>40-$ 60) $\mathrm{cm}$ menyebabkan lingkungan yang sesuai untuk mendukung aktivitas biota tanah. Kedalaman muka air tanah mempengaruhi proses dekomposisi, dimana proses dekomposisi akan berlangsung lebih cepat (Lisnawati et al., 2014). Hal tersebut terjadi karena ada ketersediaan oksigen di dalam bahan organik sehingga akan meningkatkan aktivitas mikroorganisme yang akan mengakibatkan terjadinya proses dekomposisi (Limin et al., 2000). Sejalan dengan Radjaguguk (2000) meningkatnya 
dekomposisi gambut akan meningkatkan bulk density gambut. Peningkatan aktivitas biota tanah menyebabkan nilai bulk density tanah gambut semakin besar.

Lajunya proses dekomposisi menaikkan besaran nilai bulk density. Selain aktivitas biota tanah, dekomposisi tanah gambut pada tanaman kelapa sawit dipengaruhi oleh umur tanam dan drainase. Menurut Dikas (2010), umur dan waktu pengelolaan tanaman kelapa sawit berpengaruh terhadap proses laju dekomposisi. lamanya pengelolaan kebun kelapa sawit menyebabkan laju dekomposisi gambut semakin meningkat.
Setelah didrainase, tanah akan mengalami amblesan (subsidence). Pada kurun waktu (4-10) tahun amblesan berlangsung relatif cepat dan terjadinya amblesan serta pemadatan akan mempengaruhi beberapa perubahan sifat fisika tanah berupa meningkatannya bobot isi (bulk density) dan menurunnya porositas total (Radjaguguk, 2000).

\section{Porositas}

Hasil sidik ragam menunjukkan bahwa kedalaman muka air tanah memberikan pengaruh nyata terhadap porositas di lahan gambut (Tabel 3).

Tabel 3. Rata-rata porositas tanah gambut di kedalaman (0-10) $\mathrm{cm}$ pada kedalaman muka air tanah gambut yang berbeda.

\begin{tabular}{cc}
\hline Kedalaman muka air $(\mathrm{cm})$ & Porositas $(\%)$ \\
\hline $20-40$ & $77^{\mathrm{ab}}$ \\
$>40-60$ & $73^{\mathrm{b}}$ \\
$>60$ & $80^{\mathrm{a}}$
\end{tabular}

Keterangan: Angka-angka yang diikuti oleh huruf kecil yang sama berbeda tidak nyata menurut uji DNMRT pada taraf $5 \%$

Tabel 3 menunjukkan bahwa tanah gambut pada kedalaman muka air tanah berbeda berpengaruh terhadap nilai porositas. Porositas tertinggi terdapat pada kedalam muka air $>60 \mathrm{~cm}$. Menurut Driessen (1978) sifat fisika tanah gambut merupakan produk dari banyak perubahan yang berinteraksi, yang menghasilkan bahan yang beragam dalam derajat dekomposisi. Peningkatan porositas pada tinggi muka air tanah gambut $>60 \mathrm{~cm}$, dikarenakan bobot isi yang rendah dampak dari bahan organik yang banyak belum terdekomposisi sehingga menyebabkan

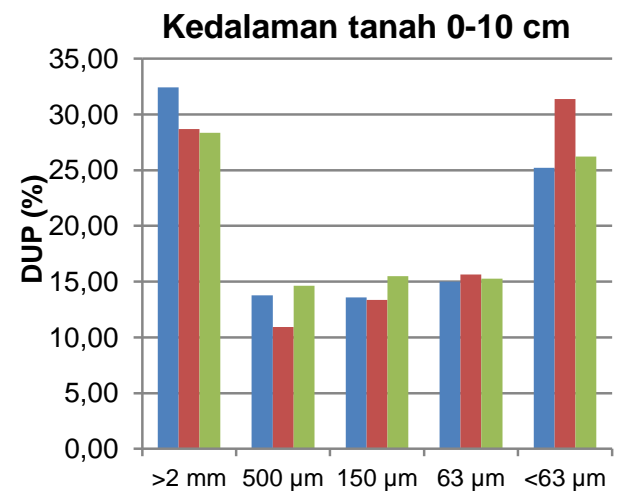

porositas yang tinggi dengan proporsi poripori besar yang tinggi (Driessen, 1978). Belum terdekomposisinya bahan dapat dilihat bahwa pada ketinggian muka air $>60$ memiliki bulk density (Tabel 2) terendah dibandingkan dengan ketinggian muka air tanah gambut yang lain. Porositas total akan menurun dengan meningkatnya dekomposisi (Radjaguguk, 2000).

\section{Distribusi Ukuran Partikel}

Hasil pengamatan rata-rata Distribusi Ukuran Partikel (DUP) tanah gambut disajikan pada Gambar 1.

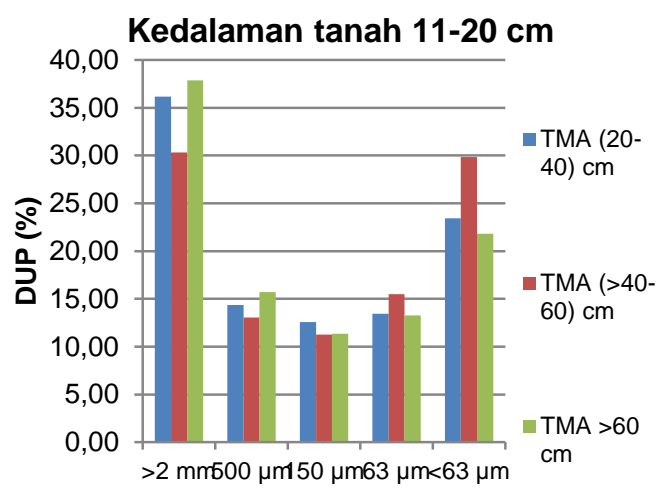

Gambar 1. Grafik perubahan Distribusi Ukuran Partikel (DUP) gambut dengan kedalaman muka air tanah berbeda.

Grafik pada Gambar 1 menunjukkan bahwa susunan tingkat kekasaran gambut di 
ketinggian muka air tanah $(>40-60) \mathrm{cm}$ pada kedalaman tanah (0-10) $\mathrm{cm}$ mengalami peningkatan sebaran partikel halus di ukuran $63 \mu \mathrm{m}$ dan ukuran kurang dari $63 \mu \mathrm{m}$ dibandingkan dengan kedalaman muka air $(20-40) \mathrm{cm}$ dan $>60 \mathrm{~cm}$. Pada kedalaman tanah (>10-20) cm dengan ketinggian muka air tanah sama mengalami penurunan sebaran partikel halus di ukuran $<63 \mu \mathrm{m}$.

Proses budidaya tanaman kelapa sawit pada tanah gambut mempengaruhi pematangan tanah gambut yang berdampak terhadap tingkat ukuran partikel halus. Penurunan kadar serat gambut sebagai akibat dari meningkatnya kematangan tanah yang disebabkan penggunaan lahan untuk kebun kelapa sawit karena semakin tinggi tingkat kematangan bahan gambut, kadar serat akan mengalami penurunan dan ukuran partikel gambut menjadi lebih halus dan lebih kecil (Dikas, 2010).

Kematangan tanah gambut disebabkan oleh proses dekomposisi yang menyebabkan peningkatan sebara partikel halus dan naiknya nilai Bulk density adalah manifestasi dari banyaknya partikel halus akibat dari proses dekomposisi. pada kedalaman muka air tanah (>40-60) mengalami peningkatan nilai bulk density dari kedalaman muka air $>60$ dan (20-40) $\mathrm{cm}$ (Tabel 2). Perubahan bulk density adalah dampak dari sebaran partikel halus, proses dekomposisi mengakibatkan peningkatan sebaran partikel halus yang menyebabkan nilai bulk density mengalami peningkatan. Perubahan bulk density gambut juga bisa disebabkan oleh konsolidasi bahan gambut akibat proses drainase atau adanya perubahan beban/tekanan di permukaan gambut (Dariah et al., 2012).

\section{Produktivitas Kelapa Sawit}

Hasil sidik ragam menunjukkan bahwa faktor kedalaman muka air tanah berpengaruh tidak nyata terhadap Produktivitas kelapa sawit di lahan gambut (Tabel 4).

Tabel 4. Rata-rata produktivitas kelapa sawit pada kedalaman muka air tanah gambut yang berbeda.

\begin{tabular}{cc}
\hline Kedalaman muka air $(\mathrm{cm})$ & Produktivitas $\left(\right.$ ton.ha $^{-1} \cdot$ tahun $^{-1}$ ) \\
\hline $20-40$ & $17.54^{\mathrm{a}}$ \\
$>40-60$ & $12.75^{\mathrm{b}}$ \\
$>60$ & $14.45^{\mathrm{b}}$ \\
\hline
\end{tabular}

Keterangan: Angka-angka yang diikuti oleh huruf kecil yang sama berbeda tidak nyata menurut uji DNMRT pada taraf $5 \%$

Tabel 4 menunjukkan bahwa tanah gambut pada kedalaman muka air tanah $(20-40) \mathrm{cm}, \quad(>40-60) \mathrm{cm}$ dan $>60 \mathrm{~cm}$ mempengaruhi nilai produktivitas secara nyata. Pada Kedalaman muka air tanah gambut (20-40) $\mathrm{cm}$ berbeda nyata dengan kedalaman air tanah gambut $(>40-60) \mathrm{cm}$ dan $>60 \mathrm{~cm}$, sedangkan kedalaman muka air tanah (20-40) cm dan $>60 \mathrm{~cm}$ memiliki perbedaan yang tidak nyata.

Menurut hasil penelitian Winarna (2015), pada tanaman umur 6 tahun dengan kedalaman muka air tanah (30-50) cm, memiliki produksi 19.92 ton.ha $^{-1} \cdot$ tahun $^{-1}$, (45-70) cm memliki produksi 19.43 ton. ha ${ }^{-1} \cdot$ tahun $^{-1}$ dan kedalaman $(70-90) \mathrm{cm}$ memiliki produksi 19.53 ton.ha ${ }^{-1} \cdot$ tahun $^{-1}$. Hal ini menunjukkan bahwa kedalaman muka air tanah lebih dari $40 \mathrm{~cm}$ mengalami penurunan dibandingkan dengan penelitian Winarna (2015) pada muka air tanah (45-70) $\mathrm{cm}$ dan $(70-90) \mathrm{cm}$.

Pada lokasi yang berbeda dan umur yang lebih muda di kedalaman muka air $(>40-60) \quad \mathrm{cm}$ menghasilkan produktivitas 17.11 ton. ha ${ }^{-1}$.tahun ${ }^{1}$, kedalaman muka air $>60 \mathrm{~cm}$ menghasilkan produktivitas 18.16 ton.ha ${ }^{-1}$.tahun. ${ }^{-1}$. Penurunan produktivitas kelapa sawit pada kedalaman muka air tanah (>40-60) $\mathrm{cm}$ dan $>60 \mathrm{~cm}$ di PT. Tabung Haji Indo Plantations diduga disebabkan oleh cendawan Ganoderma yang mengakibatkan busuk pangkal batang. Beberapa kebun di Indonesia, Ganoderma telah menyebabkan kematian kelapa sawit hingga $80 \%$ atau lebih populasi kelapa sawit dan hal tersebut menyebabkan penurunan produk kelapa sawit persatuan luas (Susanto, 2002). Umur tanaman juga dapat menurunkan produksi kelapa sawit, karena menurut Saragih (2015), produksi maksimum kelapa sawit umumnya tercapai pada umur 15 tahun, kemudian menurun seperti halnya pada tanah mineral. Selain menurunkan produktivitas, umur tanaman yang semakin tua juga menyebabkan 
tanaman mudah terserang penyakit tanaman karena daya tahan tanaman yang semakin lemah.

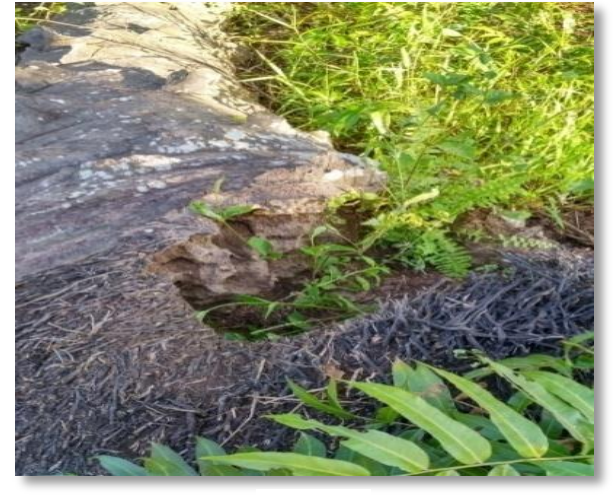

(A)

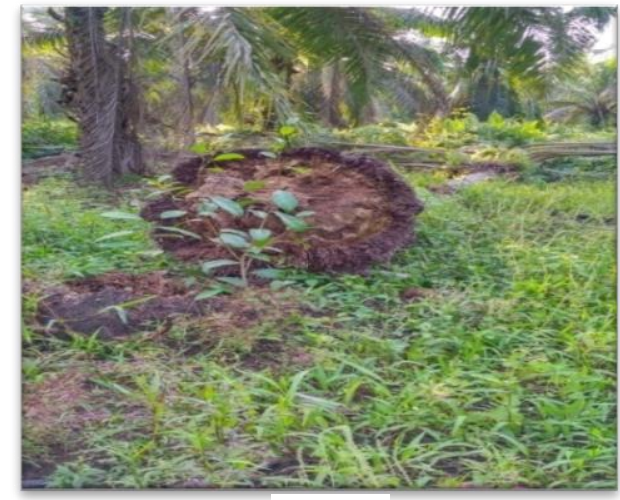

(B)

Gambar 2. Sawit terserang Ganoderma pada kedalaman muka air $>60$ (A), Sawit terserang Ganoderma kedalaman muka air $(>40-60) \mathrm{cm}(B)$.

\section{KESIMPULAN}

Berdasarkan hasil penelitian yang telah dilakukan dapat disimpulkan bahwa:

1. Tanah gambut dengan kedalaman muka air (20-40) cm memiliki kadar air lapang dan kadar air kapasitas lapang lebih tinggi dibandingkan kedalaman muka air $(>40-60) \mathrm{cm}$ dan $>60 \mathrm{~cm}$. Bulk density dan ukuran partikel halus $(\leq 63 \mu \mathrm{m})$ tanah gambut pada kedalaman muka air $(>40-60) \mathrm{cm}$ lebih tinggi dibandingkan kedalaman muka air $(20-40) \mathrm{cm}$ dan $>60 \mathrm{~cm}$ dan porositas tanah gambut pada kedalaman muka air $>60 \mathrm{~cm}$ lebih tinggi dibandingkan (20-40) $\mathrm{cm}$ dan $(>40-60)$ $\mathrm{cm}$.

2. Tanah gambut dengan kedalaman muka air (20-40) cm memiliki produktivitas kelapa sawit lebih tinggi dibandingkan dengan kedalaman muka air $(>40-60) \mathrm{cm}$ dan $>60 \mathrm{~cm}$. Produktivitas kelapa sawit $(>40-60) \mathrm{cm}$ dan $>60 \mathrm{~cm}$ lebih rendah dibandingkan (20-40) cm disebabkan oleh serangan Ganoderma.

\section{DAFTAR PUSTAKA}

Andriesse J.P. 2003. Ekologi dan Pengelolaaan Tanah Gambut Tropika. Cahyo Wibowo dan Istomo (penerjemah). Bogor: Fakultas Kehutanan, Institut Pertanian Bogor.
Arsyad. 2000. Konservasi Tanah dan Air. IPB Press. Bogor.

Dariah, A. E. Susanti, A. Mulyani, dan F. Agus. 2012. Faktor penduga karbon tersimpan di lahan gambut. Prosiding Seminar Nasional Pengelolaan Lahan gambut Berkelanjutan. BBSDLP. 213-223.

Dikas, T.M. 2010. Karakterisasi Fisik Gambut di Riau Pada Tiga Ekosistem (Marine, Payau, Dan Air Tawar). Skripsi. Institut Pertanian Bogor. Bogor.

Driessen P.M. dan L. Rochimah. 1976. The physical properties of lowland peats from Kalimantan. In proceedings of peat and podsolic soils and their potential of agriculture in Indonesia. Soil Research Institute. Bogor.

Driessen P.M. 1978. Peat soils. Soils and Rice . IRRI. Los Banos, Philippines.

Limin, S., Layuniati., and Y. Jamal. 2000. Utilization of Inland Peat for Food Crop Commodity Development Requires High Input and is Detrimental to Peat Swamp Forest Ecosystem. Proc. International Symposium on Tropical Peatlands 22-23 November 1999. Bogor.

Lim, K.H., S.S. Lim, F. Parish and R. Suharto. 2012. RSPO Manual on Best Management Practices (BMPs) for Existing Oil Palm Cultivation on Peat. Kuala Lumpur (MY): RSPO. 
Lisnawati, Y., S. Haryono, P. Erny dan Musyafa. 2014. Hubungan Kedekatan Ekologis Antara Fauna Tanah Dengan Karakteristik Tanah Gambut Yang Didrainase Untuk HTI Acacia crassicarpa. Jurnal Manusia Dan Lingkungan, 21(2): 170-178.

Radjagukguk, B. 2000. Perubahan sifatsifat fisik dan kimia tanah gambut akibat reklamasi lahan gambut untuk pertanian. Jurnal IImu Tanah dan Lingkungan. 2(1): 1-15.

Saragih, J.M. 2015. Pengelolaan lahan gambut di perkebunan kelapa sawit di kebun teluk bakau, PT Bhumiperkas nusa sejati, Minamas plantation, Riau. Skripsi (Tidak dipublikasikan). Institut Pertanian Bogor. Bogor.

Situmorang, P.C., Wawan dan M.A. Khoiri. 2015. Pengaruh kedalaman muka air tanah dan mulsa organik terhadap sifat fisik dan kimia tanah gambut pada perkebunan kelapa sawit (Elaeis guineensis Jacq.). Jurnal Online Mahasiswa Fakultas Pertanian, 2(2): 1-15.

Sukarman. 2011. Tinggi permukaan air tanah dan sifat fisik tanah gambut serta hubungannya dengan pertumbuhan Acacia crassicarpa A. Cunn Ex Bent. Thesis. Fakultas Pertanian Universitas Riau.

Susanto, A. 2002. Kajian Pengendalian Hayati Ganoderma boninense Pat. Penyebab Busuk Pangkal Batang Kelapa sawit. Disertasi. Institut Pertanian Bogor. Bogor.

Tahrun, M., Wawan, dan A.I. Amri. 2015. Perubahan sifat fisik gambut akibat kebakaran di desa Teluk binjai Kecamatan Teluk meranti Kabupaten Pelalawan. Jurnal Online Mahasiswa Faperta, 2(1): 113

Wahyunto, R.S, Suparto, H. Subagjo. 2005. Sebaran Gambut dan Kandungan Karbon di Sumatera dan Kalimantan. Wetlands International Indonesia. Bogor.

Winarna. 2015. Pengaruh Kedalaman Muka Air Tanah dan Dosis Terak Baja terhadap Hidrofobisitas Tanah Gambut, Emisi Karbon dan Produksi Kelapa Sawit. Disetasi. Institut Pertanian Bogor. Bogor. 
Sifat Fisika Tanah dan Produktivitas Kelapa Sawit di lahan Gambut (Wawan dkk, 2019) 